\title{
Reversing the Tide of Aid: Investigating Development Policy Sovereignty in the Pacific
}

John Overton, Gerard Prinsen, Warwick E. Murray et Nicki Wrighton

\section{OpenEdition}

Édition électronique

URL : http://journals.openedition.org/jso/6713

DOI : $10.4000 /$ jso. 6713

ISSN : $1760-7256$

Éditeur

Société des océanistes

\section{Édition imprimée}

Date de publication : 31 décembre 2012

ISBN : 978-2-85430-033-8

ISSN : 0300-953x

\section{Référence électronique}

John Overton, Gerard Prinsen, Warwick E. Murray et Nicki Wrighton, «Reversing the Tide of Aid:

Investigating Development Policy Sovereignty in the Pacific », Journal de la Société des Océanistes [En ligne], 135 | 2012-2, mis en ligne le 01 mars 2013, consulté le 13 novembre 2019. URL : http:// journals.openedition.org/jso/6713; DOI : 10.4000/jso.6713 


\title{
Reversing the Tide of Aid: Investigating Development Policy Sovereignty in the Pacific
}

by

\author{
John OVERTON*, Gerard PRINSEN** , Warwick E. MURRAY* and \\ Nicki WRIGHTON*
}

\begin{abstract}
Since the early 2000s, international development cooperation principles emphasise recipient countries' ownership of policies, donors' alignment with the recipients' administrative processes, and harmonisation of donor processes. Overall, this should enhance the development policy sovereignty in the Pacific Island countries and polities. Since 2011 researchers from Victoria University, Massey University, the University of the South Pacific, and the University of New Caledonia have investigated the impact of changing aid modalities on development policy sovereignty in the Pacific. The research includes a range of polities: independent states, semi-autonomous territories, as well as dependent territories. First findings suggest aid policies in the Pacific unfold in unique ways and 'aid' is just one of the flows of resources between Pacific Islands and post-colonial powers. Moreover, the relationship between aid and sovereignty is more than one of donor and recipient; it also contains elements of, and space for, agency by Pacific peoples.
\end{abstract}

KeYwORds: Pacific, aid policies, sovereignty, local agency, comparative research

The region of Oceania presents an interesting arena for the study of international development

\section{RÉSUMÉ}

Depuis les années 2000, les principes de coopération internationale veulent que les pays bénéficiaires d'aides définissent eux-même leurs politiques de développement, afin de renforcer la souveraineté des entités politiques du Pacifique dans cette formulation, et que les bailleurs de fonds, développant une approche concertée, s'alignent sur les procédures administratives locales. Depuis 2011, des chercheurs de l'Université Victoria, de l'Université Massey, de l'Université du Pacifique Sud et de l'Université de la Nouvelle-Calédonie s'intéressent aux conséquences de ce changement des modalités de l'aide sur la souveraineté des États du Pacifique en matière de politiques de développement, grâce à la sélection d'un éventail varié d'entités politiques : États indépendants, territoires semi-autonomes et territoires dépendants. Les premiers résultats suggèrent que les politiques d'aide dans le Pacifique se déploient selon des modalités uniques, l'aide ne constituant qu'un aspect des flux de ressources entre États insulaires et puissances postcoloniales. Trop complexes pour se résumer à la relation bailleur de fonds-pays bénéficiaire, les liens entre aide et souveraineté offrent un cadre où les habitants $d u$ Pacifique expriment une capacité d'action autonome.

Mots-CLÉS : Pacifique, politique d'aide, souveraineté, adaptation locale, recherche comparée

aid. Countries in the region are amongst the highest per capita recipients of aid in the world,

\footnotetext{
* School of Geography, Environment and Earth Sciences, Victoria University of Wellington, New Zealand, john.overton@vuw.ac.nz, warwick.murray@vuw.ac.nz,nicki.wrighton@vuw.ac.nz

** School of People, Environment and Planning, Massey University, Palmerston North, New Zealand, G.Prinsen@massey.ac.nz
} 
though these figures are highly variable within the region and the aggregate volume of aid to the region is very small on the global scale. When we analyse the phenomenon of aid in Oceania complex issues emerge that have implications for our understanding of development assistance more generally, relating, for example, to the definition of aid, the relationship between sovereignty and aid and the importance of local agency in the global aid landscape. Overall, comparative research in Oceania provides the opportunity to glean a systematic insight into the diversity of ways that the global aid agenda of the 2000s has influenced outcomes at national, regional and local scales.

This paper begins with an overview of the international aid agenda of the past decade and the manifestations of this in Oceania. It then moves to analyse two key aspects of aid in the Pacific: firstly, the diversity of aid regimes as well as debates concerning the definition of aid, and secondly the contentious and complex issue of sovereignty as it relates to aid. A current research project on aid in the Pacific is then outlined before some conclusions are drawn commenting in particular on the need to reimagine aid, agency and autonomy.

\section{Context: The global aid regime and the Pacific region}

Since the adoption in 1999 of the Millennium Development Goals (MDGs), backed by the United Nations, development aid has been transformed at the global scale. The MDGs themselves not only helped serve as a catalyst for donor countries to increase their aid budgets but were also particularly influential in focusing aid on poverty alleviation and providing targets against which the performance of aid could begin to be measured. Through the first decade of the 2000s, development aid (as measured by the Development Assistance Committee [DAC] of the OECD) grew significantly in both volume and as a percentage of donor countries' national income. This trend was also affected by the aftermath of the 9/11 terrorist attacks in USA and related incidents in Europe and Southeast Asia. Western governments were greatly concerned that politically unstable and economically poor countries could become a haven for terrorist groups and they used aid as a key instrument in helping to support and build the functional capacity of 'fragile' states particularly in terms of delivering basic welfare services and law and order (Barbara, 2006). It was a move towards the 'securitization' of aid (Howell and Lind, 2008 ; Shannon, 2009). These shifts marked a departure from the early aid regimes of 'pure' neoliberalism in the late 1980s and 1990s, which had sought to promote market-led development strategies and lessen the role of the state, and could be characterised as 'neostructural' in character (Murray and Overton, 2011a, 2011b).

A further key international agreement that influenced global development aid in the 2000s was the Paris Declaration on Aid Effectiveness of 2005. This agreement, brokered by the DAC and signed by the major donors - as well as many recipient governments - sought to improve the effectiveness of aid. Having agreed to an increase in aid budgets, donors sought to ensure that the aid they were granting reached the intended recipients. In this sense, the Paris Declaration was arguably more concerned with the efficiency of aid delivery than the effectiveness of the spending in terms of development outcomes, as defined by the MDGs. Nonetheless, the Paris Declaration marked a significant and potentially revolutionary change in the way aid was conceived and delivered and it represented a remarkable consensus amongst most of the aid community. The Declaration was built around five core principles: ownership, alignment, harmonisation, mutual accountability and management for results. The first of these ownership - was pivotal. It recognised and encouraged the 'ownership' of development strategies - and by implication the financial resources that flowed from aid receipts - by recipient countries. It asked these countries and their governments - to prepare strategic plans to address poverty reduction and, if acceptable, these formed the basis for long-term and sustained commitment by donors to align with these plans, harmonise their efforts (to avoid donor duplication and competition) and fund substantial development programs in areas such as health and education (Eyben, 2007). The Paris Declaration further underlined the neostructural turn by recognising the state - rather than civil society or the market - as the key agency for development. 'Ownership' was thus predicated on the state - a sovereign state that putatively defined and led 'development' (Williams, 2000; Buiter, 2007).

Overall then this new aid regime involved a strong rhetorical approach that supported and built state sovereignty. Furthermore, this rhetoric was underpinned by changes in aid modalities. These again moved the aid regime away from the old aid modality of discrete aid projects managed by donors towards 
programmes of financial support to public policies implemented by public administrations of sovereign states. This donor support to sovereign states, however, was conditional upon approval of the recipients' public policies such as Poverty Reduction Strategies (PRSPs) (Booth, 2003; Cheru, 2006; Dijkstra and Komives, 2011; Driscoll and Evans, 2005; Sumner, 2006) and changes to a countries' public finance management systems audited internationally via mechanisms such as Public Expenditure and Financial Accountability (PEFA) frameworks (Eifert and Gelb, 2008; De Renzio, 2006, 2009). In essence the new aid regime draws a strong line between aid and good governance: aid and aid conditionalities are used as tools to improve the efficiency, transparency and productivity of government institutions (Santiso and Nitze, 2001). Yet this is, to a large extent an exercise in rebuilding state institutions and practices in recipient countries so they more closely match those of donors (Murray and Overton, 2011a).

Acknowledging that most aid recipient states would not immediately meet the expectations of donors with regard to policies and public finance management, donors developed a set of interlinked aid modalities that envisaged increasing volumes of aid and decision-making powers by the recipients as these recipients improved their institutional capacity to manage larger volumes of aid (Booth, 2011). The inter-linked aid modalities thus range from conditional or ear-marked financial support to a particular sector such as education or health (in a so-called Sector-Wide Approach, orswap) to unconditional financial support for a recipient government's budget (General Budget Support, or GBS) (Koeberle et al., 2006).

In Oceania these changes were adopted and quickly began to reshape aid in the region. Though often seen as small and remote from the centres of the global aid industry - focused on sub-Saharan Africa or the Iraq/Afghanistan military interventions - the Pacific region was not isolated from global geopolitics. Firstly, the bombings in Bali in 2002 provided a stark reminder to Australia in particular that terrorism and political instability could affect its own citizens and its own strategic interests very close to home. Furthermore, the civil conflict in the Solomon Islands in the early 2000s, coups in Fiji, and instability in Papua New Guinea helped create an impression of an 'arc of instability' in the south-western Pacific that could pose a distinct and direct security threat to Australia, New Zealand and other countries in the region (Fry,
1997). To a large extent this concept of an arc of instability was constructed as a means of shaping Australia's foreign and defence policies rather than constituting a real and imminent threat to the security of these metropolitan countries (Dobell, 2007). The attention of these countries - along with USA, Japan, France, Britain and the European Union - turned more to a region that had been relatively neglected in the early post-Cold War years. There was a degree of direct military engagement - as with the Regional Assistance Mission to the Solomon Islands (RAMSI) initiative after 2003 - but it was development aid that was seen as the central instrument in helping to build state capacity, economic growth and social cohesion (Dinnen, 2004; Dinnen and Firth, 2008; Tabutaulaka, 2005).

Although the security concerns may have been uppermost in the minds of several donors, the poverty agenda nonetheless seemed to take an equally prominent place in the aid landscape (Storey et al, 2005). There were some protestations that poverty did not exist in the Pacific, at least not in the same sense as the grinding poverty and hunger in evidence elsewhere. Even so, marked poverty and inequality do exist in the Pacific. For example, in one of the comparatively richer per capita territories - French Polynesia a strong inequality between various segments of the population results in the juxtaposition of the genuinely poor and substantially rich (Herrera and Merceron, 2010). Against this background, but as much driven by the global consensus to address the MDGs, these poverty reduction goals were rolled out across the region helping to identify key sectors of concern and both donor agencies and recipient governments began to design and implement some major programmes, especially in the health and education sectors (Naidu and Wood, 2008; Naidu, 2009; Kidu, 2009; Feeny and Clarke, 2008). It was perhaps no coincidence that the MDGs and the poverty agenda helped pinpoint the location of areas of concern for aid - Papua New Guinea, the Solomon Islands, Vanuatu and Kiribati - that largely coincided with the security-driven arc of instability concerns. Chand's (2011) analysis of Australian aid shows that poverty is only a significant factor in the distribution of that country's aid after it has chosen recipients on seemingly geopolitical grounds.

A snapshot of development aid to the Pacific region in 2009 reveals some interesting insights into the way this new aid regime developed. Figure 1 shows the distribution of total 


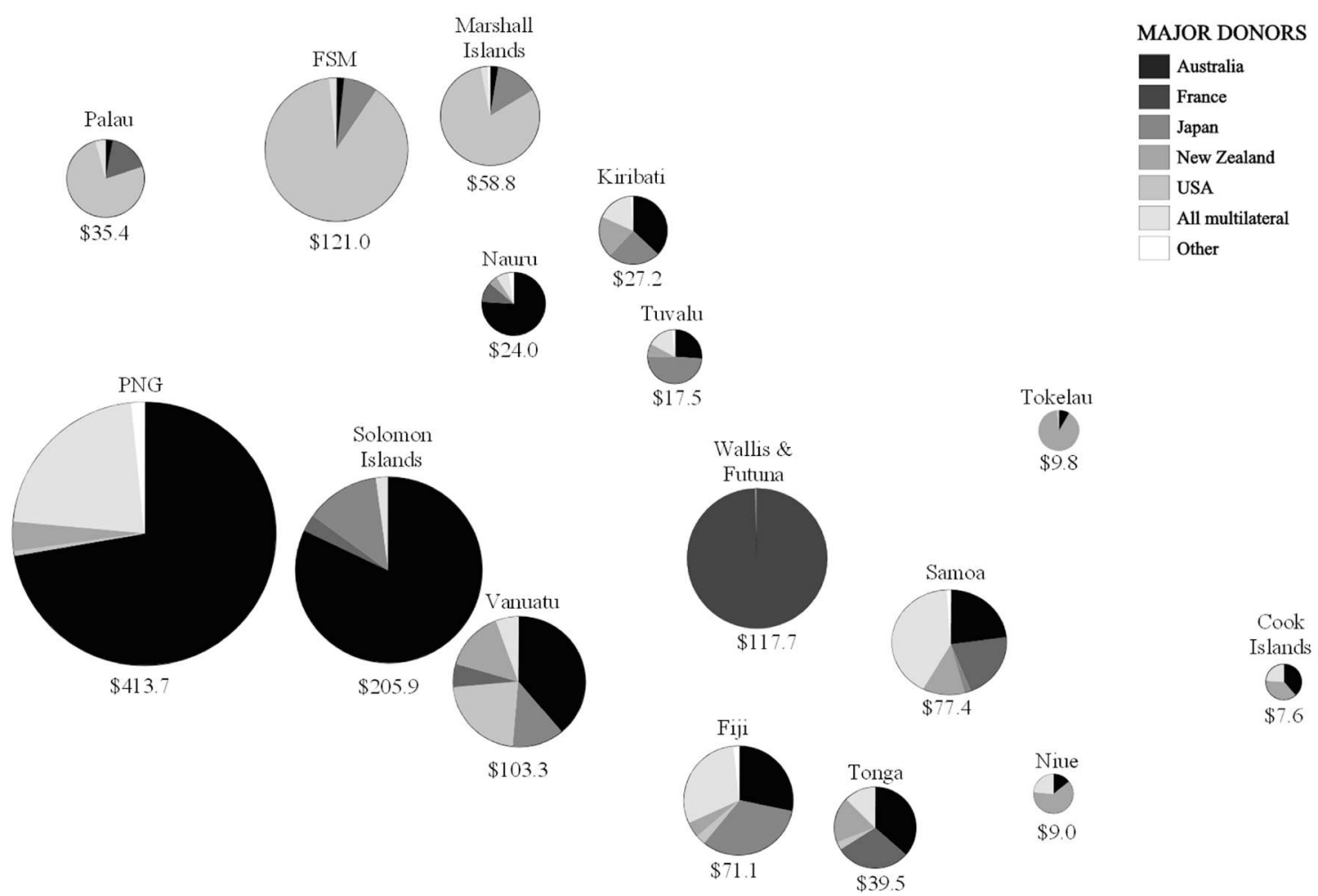

FIgURE 1. - Official Development Assistance to Pacific Island Countries 2009 (US \$ millions) (Source: Data extracted from http://stats.oecd.org/ in July 2011)

development aid (ODA) $)^{1}$ to the region in an absolute sense. Three points are apparent from this map. Firstly, Melanesian states and territories, particularly Papua New Guinea and the Solomon Islands, dominate the allocation in terms of total volume. This suggests that a combination of the poverty agenda and security concerns have been the main factors in determining aid flows. Secondly, and a little more opaque, is the way most recipient countries are dominated by a single donor and this 'patron' is usually defined by a former colonial status. Thus Australia dominates in PNG, France in the French territories of Wallis and Futuna (also French Polynesia and New Caledonia, though these are not included in these data, just as Rapa Nui is excluded being a province of Chile, and Hawai'i as a state in USA), the USA in Micronesia and New Zealand in Niue, the Cook Islands and the Tokelau Islands. Furthermore, when it is remembered that Britain largely disengaged from the region following the independence of its former territories Fiji, the Solomon Islands and (partly)
Vanuatu - to be largely replaced by Australia the neo-colonial drawing of the aid map becomes even more stark. Indeed the only major non-colonial players in the Pacific aid landscape are Japan which significant in Kiribati, Fiji, Tonga and Tuvalu, and China (and Taiwan), to which we will turn shortly. The third feature is that the major aid recipients in an absolute sense, especially those in Melanesia (PNG, the Solomon Islands, Vanuatu and Fiji) are all sovereign independent states. This is also the case for other significant recipients: Samoa, Kiribati and Tonga.

A second snapshot of aid in the region - this time based on aid per capita (Figure 2) - reveals a rather different landscape. Here we see not the dominance of the Melanesian states - Papua New Guinea indeed has the lowest per capita receipts - but rather it is the small states, especially in Polynesia and Micronesia that are the major recipients. Some of these - Wallis and Futuna, Tokelau, Niue - have amongst the highest per capita aid levels in the world. Clearly

1. These data, from the OECD, only include financial flows captured by the OECD definition of aid (so-called 'DAC-able' aid). They exclude aid from China and other countries not party to DAC and also, as we shall see, significant flows of funds from metropolitan governments (France and the USA in particular) to Pacific territories and dependencies. Hawai'i and Rapa Nui (Easter Island) are excluded also as they are deemed to be an integral part of USA and Chile respectively. 


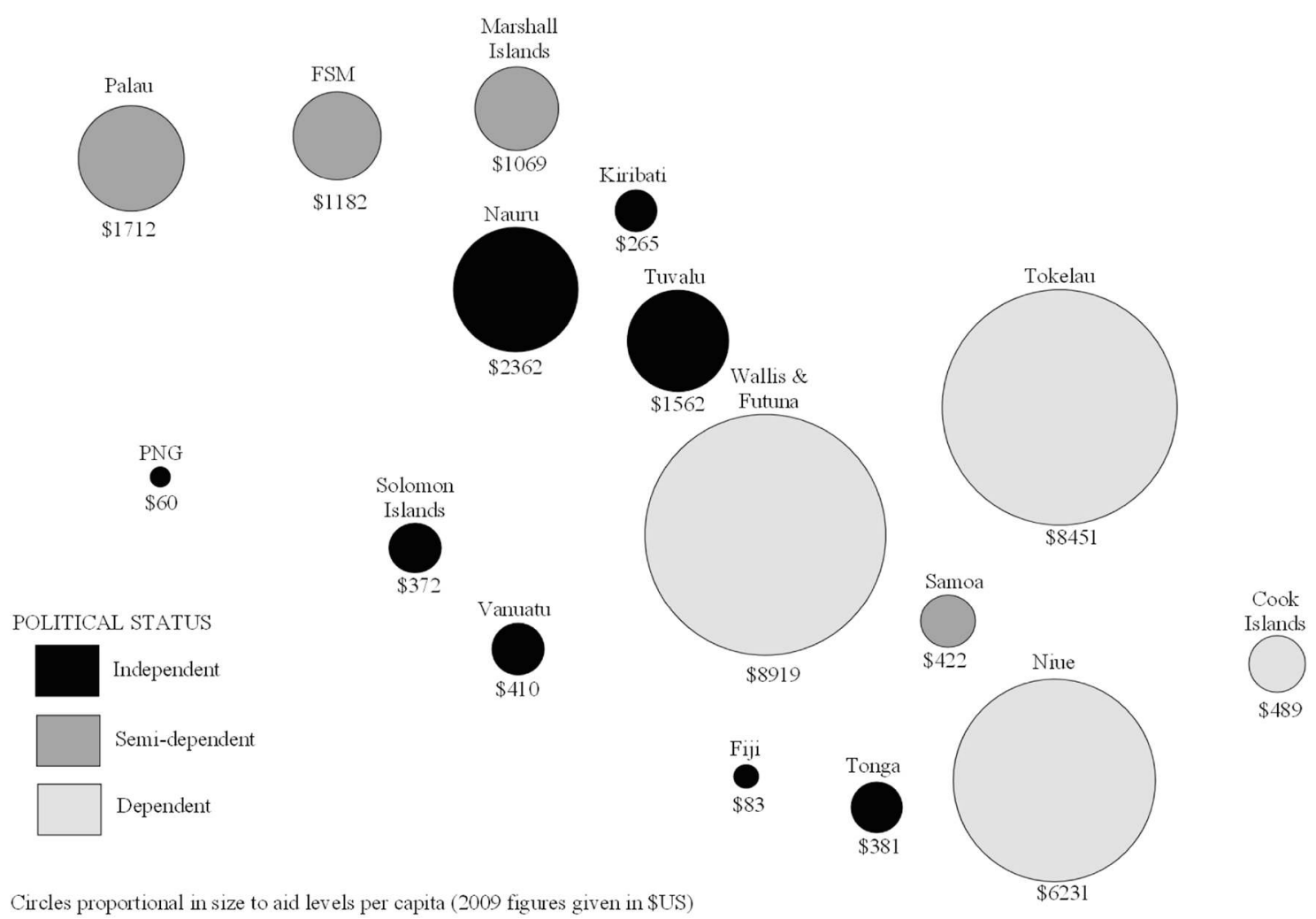

FIGURE 2. - Per Capita Official Development Assistance to Pacific Island Countries 2009 (US \$) (Source: Data extracted from http://stats.oecd.org/ in July 2011)

neither poverty alleviation nor security concerns are driving these very high levels of aid, for these states are politically stable and have relatively very favourable welfare indices. Instead it appears that they are favoured because they are not independent sovereign states but rather, variously constituted dependencies and semiindependent states whose close relationships to the metropolitan patron secures them very high levels of support, together with a very high level of dependence on a single donor (Bertram, 2006).

Thus, when we look at this broader context of development aid in the Pacific, we can begin to ask some important questions and start to question the frameworks and definitions we employ. Firstly, a simple transfer of the global aid regime to the Pacific - one shaped by the MDGs, the Paris Declaration and the securitisation of aid - does not help us explain the complexities that are apparent with even an elementary examination of absolute or relative (per capita) aid flows. Secondly, reliance on OECD aid data and definitions, whilst important for standardising aid statistics, masks what we suspect are more varied and complex flows of resources and from a wider range of donors - something we turn to below. Finally, our conventional frameworks for analy- sing the region - whether based on the cultural Melanesia/Polynesia/Micronesia categories; the French/American/British/Australasian (neo-) colonial spheres of influence; or the environmental large/small islands framework - do not serve us well. There are clearly interesting commonalities across the divides, particularly if we broaden our understanding of 'aid', but equally important and more opaque contrasts. It is to these complexities and possibilities that we now turn.

\section{What is Aid?}

The definition and measurement of aid by the OECD - and indeed the very concept of aid needs to be critically questioned in relation to the Pacific region. The maps above gave two views of aid in the region but, as already suggested, these are an inadequate and misleading portrayal of the ways resources flow between Pacific Islands and metropolitan states.

We have seen how patron donor states usually former colonial powers - dominate the aid receipts of several Pacific countries. Dependence on these patrons leads to higher volumes of aid and other benefits but it also involves 
greater reliance on and, potentially, control by, the metropole. In these highly dependent Pacific states, aid helps support the daily operation of the state, either directly or because aid can be fungible. For example in this latter case, aid for education through scholarships to attend universities overseas can free up recipient state resources to spend in other areas of education. Aid can support state functions at a higher level than local revenue sources could sustain and welfare services (and provision of health and education) provided by the state can be significant, compared to low-aid states. This can be seen in highly aid-dependent states such as Tokelau or Niue. But, how do we define and measure 'aid' in territories that are highly or wholly integrated with their metropole? At its most extreme, we might point to the case of Hawai'i, one of the states of USA, fully integrated into that country but still a 'Pacific Island state'. The same could be said of Rapa Nui (Easter Island), a Pacific Island that is fully integrated within Chile. Neither Hawai'i nor Rapa Nui receive 'aid', though one suspects that there are significant flows of resources from the mainland that are intended for what we might broadly define as 'development' purposes. In the case of Hawai'i it is likely that net government financial flows are positively skewed towards Hawai'i but for Rapa Nui, there may be a negative flow, at least when combined with private flows ${ }^{2}$.

Us territories in the Pacific other than Hawai'i have various constitutional arrangements that link them to USA. American Samoa, for example has been an integrated territory of the USA since 1900 but it has its own constitution and its citizens are classified as us nationals but not citizens. The territory elects its own legislature but does not vote in federal elections nor pay federal taxes. It does not receive aid (ODA) from USA though it does receive federal grants to support government of the territory to the tune of \$US 102 million - out of total government spending of \$ 179 million (in 2007 - USA Office of Insular Affairs, 2011). Though not called 'aid' this financial flow is significant and equivalent to 21 percent of the territory's GDP. Added to this direct grant from USA, we need to consider a range of other net financial flows such as that of the military, direct payment of federal employees, and some expenditure by federal departments operating in the territory. These all constitute a highly significant inflow of money that support employment and services and material standards of living well above what they would be without such processes ${ }^{3}$. Elsewhere in the Pacific, we might see similar disguised 'aid' flows to Guam and perhaps the Northern Mariana Islands. While other former territories such as Palau and the Marshall Islands do receive ODA from the USA that is captured by the OECD, there is likely to be additional expenditure that is not.

The French territories of the Pacific have similar characteristics to the US territories in this regard. Again there is a diversity of constitutional arrangements that bind them to metropolitan France and only a fraction of the financial flows are counted as 'aid' according to the OECD-DAC conventions. Wallis and Futuna is considered sovereign; French aid to the country is recognised as ODA. Indeed these flows are the highest on a per capita basis in the region. The flows support the operation of government and welfare provision but are unlikely to be the only financial flows that come from the metropole. In fact, the people from Wallis have emigrated in large numbers to New Caledonia in successive 'waves' since the 1950s, pushed by poverty at home and pulled by jobs in the mining industry overseas (Baudchon and Rallu, 1999; Nedelec, 2010). While this formally constitutes merely 'moving residence within a country', the pertaining revenue streams are classic MIRAB features (sea below).

The two largest French territories in the region, New Caledonia and French Polynesia, present an unusual and interesting examples of the inadequacies of definitions and measurement of aid. Figures 1 and 2 above reveal no official aid flows into these two territories in 2009. Not recognised, for instance, are the resources flowing to the two countries/territories under the banner of the French Development Agency (AFD). At first, this lack of aid is not surprising: both have very high per capita incomes and their health and education services are very well-funded. The mining and tourism industries provide endogenous forms of income. However, such a picture is highly misleading. The residents of the two territories are French

2. Understanding net financial flows in this regard in Rapa Nui represents a gap in the literature and a challenge for research. Rapa Nui is a province in Chile's Region of Valparaíso Region IV and revenues flow inwards from national and regional government for infrastructure, services and other provincial functions. There are also significant flows that arrive through the national government's development arm CORFO as well as other aligned state arms. It is believed that significant revenues flow out from tourism and rents to pay for education of Rapa Nui in the Chilean mainland. However, this potential inverse MIRAB effect (see below) is based on anecdotal reflection only at this stage.

3. Material standards here refer to monetary income. These inflows may have broader negative impacts including unequal distributional impacts and negative nutritional impacts that may detract from living standards more broadly defined. 
citizens, vote in metropolitan as well as local elections and are free to move between the territory and metropolitan France. Even an almost cursory glance at the flow of resources from the French Treasury to these territories, reveals the enormous significance of metropolitan aid to the Pacific territories, even if it is formally presented - or rather conveniently obscured - as 'intra-state' transfers.

In New Caledonia, for example, the overall contribution of metropolitan resources to the total GDP is estimated to be about $18.5 \%$, or 1.14 billion euros per year (Hadj et al., 2011: 5). These transfers mostly come in three ways, each benefitting a particular segment of society in New Caledonia. First, metropolitan resources come to New Caledonia in the form of salaries, pensions and associated costs for civil servants amounting to an estimated 1.08 billion euros a year. Second, metropolitan France contributes about 80 million euros a year in 'development contracts' for local projects negotiated individually between Paris and various administrative actors such as the government of New Caledonia, the three provincial governments and the 33 municipalities ('communes'). And finally, resources flow from Paris to New Caledonia in the form of various and negotiable tax exemptions for French businesses that invest or trade in New Caledonia. The number of eligible projects varies significantly from year to year, but tax exemptions can run into hundreds of millions of euros a year (Institut d'Émission de l'Outre-Mer (IEOM, 2011: 53-54, 65).
Although these flows to the French territories are not recorded as aid, even in part, this has not always been the case. Figure 3 shows the historical flows of aid, as measured by the OECD to the French Pacific territories. We can see that aid to New Caledonia and French Polynesia rose steadily from the mid 1960s so that they became the two highest aid recipients in absolute terms in the region for a brief period in the late 1990s. We would have had no difficulty in classifying these two places at that time as aid dependent economies. In 2000 the volumes fell to zero. This dramatic change came not because aid stopped but because it was reclassified. The flows from Paris to the Pacific were no longer seen as 'aid' but as a French grant to support the operation of government and the provision of services. A change in definition did not stop the flows of resources - they have gone on increasing since yet we do not analyse them as aid. But we do use the aid lens to examine what New Zealand, for example, sends to what some term its 'realm' territories in Niue, the Tokelau Islands and Cook Islands. These, we would argue, should be seen in a very similar way to the French and US flows and relationships. Indeed, some in governmental circles in New Zealand have suggested that such aid to its 'realm' territories should be expanded so that they receive a level of government services equivalent to a suburb in New Zealand:

«the services New Zealand funds for its three Realm territories are, in essence, services to New Zealand citizens who happen to live in isolated places overseas.» (New Zealand House of Representatives, 2010: 30)

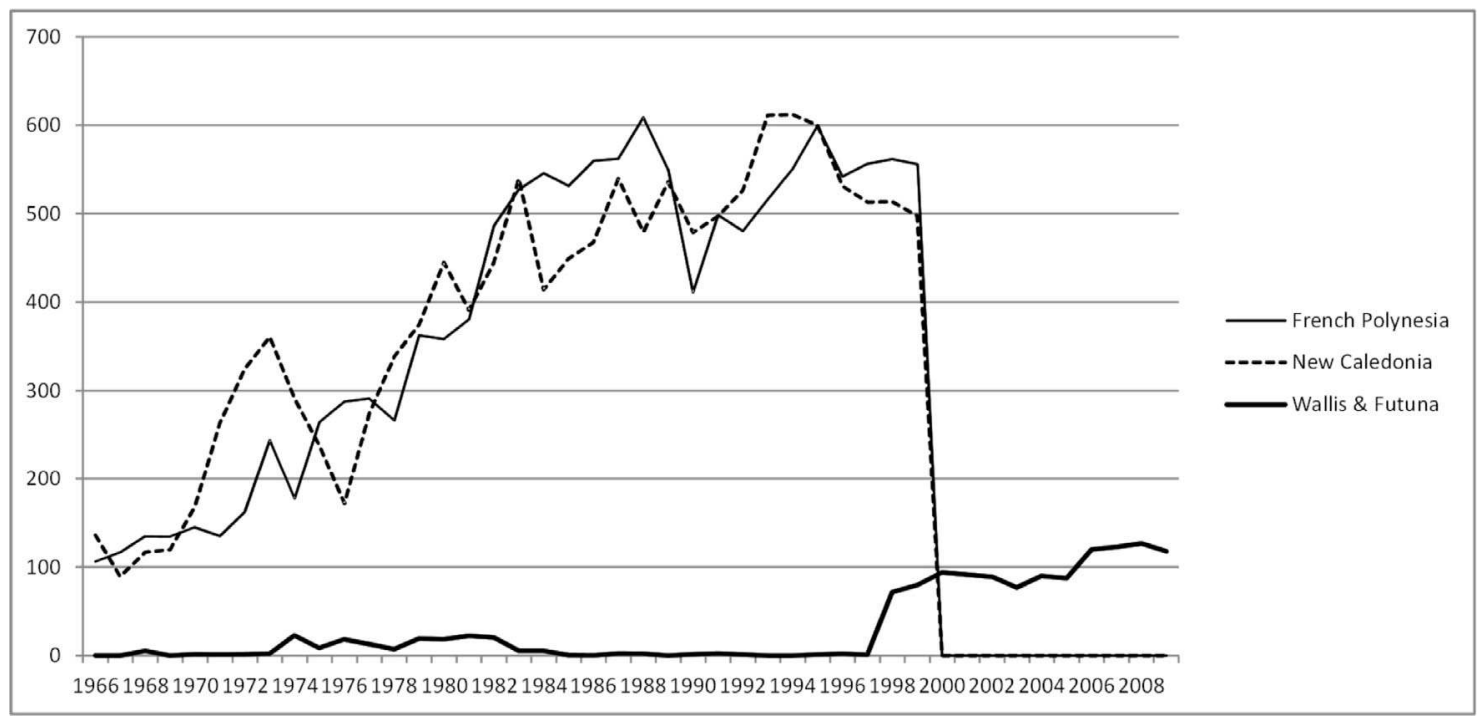

FIGURE 3. - Official Development Assistance to French Pacific Territories 1966-2009 (US \$ millions, constant prices) (Source: Data extracted from http://stats.oecd.org/ in July 2011) 
These examples of the us, French and New Zealand territories in the Pacific should alert us to the dangers of conventional analyses of aid. Arbitrary constitutional arrangements and changes in accounting definitions have distorted our view of the ways Pacific states are linked to their metropolitan patrons. 'Aid' comes in many different forms but flows from the core to the periphery to support government services are not all recognised as aid as the DAC might define it.

Furthermore, in terms of development in the Pacific, aid is only a partial contributor to overall welfare albeit one that can be highly significant in certain contexts. In the mid 1980s Bertram and Watters suggested that several Pacific Island countries could be classified as MIRAB states (Bertram and Watters, 1985; Bertram, 2004; 2006), that is that their economies were dominated by migration, remittances, aid and bureaucracy. These small states, with few natural resources and no economies of scale had bleak prospects for autonomous growth in an increasingly globalised economy. What helped them function effectively was in fact dependence on their patrons - trading independence for metropolitan support allowed them to maintain relatively high standards of living and open more options for their citizens. Aid was an important component of the MIRAB model, but of arguably greater significance was increased labour mobility, a result of the citizenship rights enjoyed by these Pacific communities that gave them easy entry to live and work in metropolitan countries and remit money home to support their families, churches, communities and businesses. Such remittances have become vital components of many Pacific economies. And they are found not only in dependent states. Some independent states such as Samoa can exploit historical ties and agreements (in this case with New Zealand) to secure preferential migration access, whilst for Fiji, demand for its nurses and soldiers overseas has opened opportunities for work abroad so that remittances now rank close to tourism and sugar as contributors its economy. Hau'ofa and others have rejected the MIRAB model because of its negative and patronising connotations and argued that it was the Oceanic approach to development - with Pacific Islanders adept at moving and exploiting resources worldwide - that was a much more viable and positive model (Hau'ofa, 1995). Perhaps the divide between Hau'ofa's 'Oceanic' approach and the MIRAB model may not be as wide as first seems if we recognise the importance of Pacific agency, initiative and opportunism rather than apparent helplessness in the face of external forces.

Migration and remittances may not seem to fit well within an aid discourse, but they do constitute important two-way flows of human and capital resources. New Zealand and Australia have recognised the development benefits of just such an approach. New Zealand first, and recently Australia, have instituted schemes to allow workers from the Pacific to engage in seasonal work on farms. This short term migration is sanctioned, organised and encouraged, with strong backing from the Pacific governments, as a means to earn income overseas that can be taken home to support both consumption and investment.

Formally organised as well as spontenous individual migration from Pacific Islands to metropolitan countries like New Zealand also expand and deepen the personal networks between the two. Samoans, Tongans, Cook Islanders, Niueans and Tokelauans now constitute nearly $7 \%$ of New Zealand's population. As such, they have not only become part and parcel of New Zealand's identity, but also begin to hold important political levers in New Zealand. Arguably, recent shifts in New Zealand's aid policies away from Pacific Islands with high poverty indices such as Papua New Guinea and the Solomon Islands and towards Pacific Islands with far better human development indices such as Samoa and Tonga - are also driven by a government's desire to court the Samoan and Tongan vote in the New Zealand electorate 4 .

In addition to migration and remittances, analyses of aid in the Pacific should also consider trade. In the late 1980s, Taylor edited a collection of research papers on Fiji and concluded that European Union trade preferences for Fiji sugar under the then Lomé Convention amounted to 'aid with dignity' (Taylor, 1987). By paying stable and higher-than-market prices for Fiji sugar, Europe supported a large and thriving industry in Fiji with significant flow-on effects to employment, transport, processing and services. It was a form of support that significantly exceeded the benefit to the Fijian economy derived directly from official aid. Later the approach to trade preferences as a form of aid was extended to encompass the Australian and New Zealand markets under the SPARTECA agreement and, for a while, a thriving garment industry flourished in

4. The use of votes as a local resource that flows from rural areas to the more powerful metropolitan capital cities in exchange for material resources flowing from the metropolis to the peripheral areas is a common dynamic in an African context, see Prinsen (2011). 
Fiji (Storey, 2004). This form of aid, though, is sharply on the wane. Global trade liberalisation has not only blunted the chances of Pacific countries gaining revenue from import tariffs but also lowered the trade preferences they enjoyed under SPARTECA and Lomé to the point where the Fiji garment has all but collapsed and the sugar industry is suffering and contracting.

As well as recognising these forms of nonfinancial aid through trade or migration concessions, our view of aid in the Pacific needs to be further expanded by recognising the activities of non DAC aid donors, particularly China. The activities of the Republic of China have become much more visible in the Pacific in the past decade, as they have in other parts of the world (Mawdsley, 2010; Mohan and Power, 2009). China is not a party to the DAC, nor is it a signatory of the Paris Declaration and the amount that it spends on aid, and under what conditions, remains shrouded (Hanson, 2008). It is often regarded with suspicion and even derision by other aid donors for the way it operates outside of the accepted (DAC) 'rules', seeming to use aid as a way of leveraging political support and of persuading recipients not to recognise the independent status of Taiwan. Although it is very difficult to measure the volume and direction of Chinese aid in the Pacific, its imprint is clear to see (Ratuva, 2011). It has been active in supporting infrastructure development and public works. It has been particularly active in building sports facilities and government buildings (as in Fiji and Samoa) and throughout the region Chinese companies are found constructing roads and bridges in remote rural areas, engaged in infrastructure projects that both other donors and local governments shun (though the latter are keen to see built). The modus operandi of Chinese aid seems to be to offer soft loans to recipients (the amount of the concession providing the 'aid') which are then used to employ Chinese contractors to directly construct the roads and buildings. This is aid, then, that is tied to Chinese suppliers and has a clear return to the Chinese economy and it does require recipients to repay their loans. It may not align with international practice in aid, as proscribed by the Paris Declaration and other agreements, but Pacific states have been keen to accept such assistance, especially as it has been in areas which other donors have been reluctant to engage in and it is often quicker and easier to access with lower transaction costs.

We have seen from this brief overview, then, that aid in the Pacific is a much more complex phenomenon than that simply defined by recorded flows of ODA. The OECD apparatus significantly underestimates flows of total aid, whether by not including non- DAC donors such as China, or by not counting flows to dependent incorporated territories such as American Samoa or New Caledonia. And it is completely blind to important non-financial flows of assistance. As we expand our frames of reference to incorporate such flows, however, our concept of aid begins to broaden and weaken. Aid is no longer merely a one-way flow of funding from donors to recipients to alleviate poverty. It is instead, perhaps, a device to encapsulate the different ways in which wealthier countries seek to exert influence over both the development strategies and political and social order of countries in the Pacific. Simultaneously, aid in its diverse forms may also be an instrument for Pacific people to negotiate or direct the flow of resources from and towards them. In this, the relationship between countries and their underlying political status and autonomy is critical.

\section{What is Sovereignty?}

The global aid regime is mainly predicated on state to state transfers, from aid donor states to sovereign recipient states. The ownership principle of the Paris Declaration strongly reinforces this view: it is recipient governments who receive and disburse aid supposedly as independent entities able to determine their own development strategies and priorities. In this context, 'sovereignty' in Western-style democracies refers to politically independent entities exercising various practices of sovereignty including upholding fixed geographic borders and determining who can reside within them, governing citizens via domestically approved policies, enforcing law and order via domestically controlled public forces, controlling a national currency or proxy thereof, and cooperating with other nation states through, for example, pursuing international treaties and bodies. In the Pacific region however, this commonly-held view of sovereignty is not sufficient. We require a broader and more flexible concept in order to capture the effective exercise of self-determination in the region (Wesley Smith, 2007).

In Oceania, sovereignty is not a simple issue: there is no straightforward divide between fully independent nation-states and territories integrated into other nation-states. There is a wide range of constitutional arrangements that define 
linkages between Pacific territories ${ }^{5}$ and their patrons. At one end of the scale are fully sovereign territories that constitute nation states, such as Papua New Guinea, Vanuatu, Tonga or Fiji, though even here the dominance of a major donor (as with Australia in PNG) means that the degree of influence held in practice by one metropolitan power does constrain some aspects of effective sovereignty. At the other end of the scale are territories (Hawai'i, Rapa Nui, etc) that are fully integrated into other independent nation-states. In this light, one might even argue that New Zealand is a Pacific Island state that has fully integrated the polities of its indigenous Polynesian (Maori) population often against the will and rights of the latter. In between these is an array of territories that are nominally independent but have one or more aspects of their sovereignty negotiated in a special relationship with their patron. There are, for example, the Cook Islands and Niue: two territories which are 'self governing' but 'in free association' with New Zealand such that its citizens have most of the rights of New Zealand citizens and, if requested, New Zealand may take on some sovereign obligations, such as defence. Samoa has a Treaty of Friendship with New Zealand recognising a former colonial relationship that has provided some special concessions for independent Samoa. The Marshall Islands has a compact with the USA that also gives it special status and support and we have noted the semi-integrated status of American Samoa. New Caledonia is part of France but is in an evolutionary process that opens the possibility of a transition to independence, a situation different to other integrated French territories.

As well as there being a range of degrees of sovereignty across the region, it appears that various constituent aspects of sovereignty itself appear to have political and strategic value that can be traded and exploited. Even small states can use aspects of their sovereign status to leverage benefits. A seat at the United Nations or international agencies, such as the International Whaling Commission, comes with a vote and a vote that may be sought (and even bought) by larger and wealthier countries. Whilst full independence may thus seem to provide bargaining power and potential for gain, the MIRAB model suggests that it is not full sovereignty but a negotiated, fluid, and evolving dependence that yields benefits from the metropole. Aid volumes are greater and opportunities for migration greatly increased when countries retain a close link to their patron. Sovereignty in the Pacific thus is a malleable concept and its constituent elements are a negotiable commodity. There is value in asserting independence but equally there is some worth in trading aspects of effective sovereignty for increased levels of support. This is the first part of what we term the 'inverse sovereignty effect' in the Pacific: higher levels of sovereignty are inversely related to material standards of living and opportunities for aid and remittances.

Yet to confine analysis of sovereignty in the Pacific simply to territorial political status misses an opportunity to explore deeper meanings of the term. Here we turn to political debates within Aotearoa/New Zealand. This nationstate was founded by a treaty between the British Crown and its various (Maori) indigenous polities - the Treaty of Waitangi of 1840. The Treaty has been a source of contention between Maori and the later arrivals (pakeha) to the nationstate. The Treaty contained an agreement that the British Crown would protect Maori sovereignty (tino rangatiratanga) ${ }^{6}$ and use of their land and resources, as well as offering full participation as British subjects and partnership in governing the nation-state. Over the years the Treaty was often neglected, ignored and not effectively passed into law. In the past 30 years however it has been revived in the country's political discourse and become a means for Maori to make claims against the nation state, or the Crown, for abuses of the Treaty, particularly over the loss of their land and resources. One of the central features of this revival has been the debate about Maori sovereignty. For some pakeha this has caused alarm that it might precipitate some form of separate government for Maori or even complete Maori control over the 'sovereignty' of the nation-state. Yet, at essence is the question of sovereignty as 'self-determination': the right of Maori to have control over their own development and, in particular, control over their own lands, customs and treasures and the right to (re-) negotiate aspects of this sovereignty, even if this lies within the geographical boundaries of the nation-state of New Zealand. This is obviously a highly contentious and politically charged debate but it does open up the possibility of seeing sovereignty in a much more

5. Here we use the term 'territory' to include all polities that exist in Oceania including independent nation states, countries in free association, integrated territories and so on.

6. There has been confusion over the Treaty as result of translations between English and Maori. The English version of the Treaty used 'sovereignty' to denote cession of absolute power to the British Crown. In the Maori version of the Treaty the term tino rangatiratanga was used and taken to mean continued Maori use and control over their resources. 
practical and less legalistic sense, namely how self-determination is exercised and performed on a day-to-day basis by individuals and communities that co-exist.

We suggest this more complex and nuanced understanding of sovereignty is important for how we see aid in the Pacific and how we unravel and analyse the relationships between Pacific peoples, communities, nations and states and their metropolitan 'partners' and/or patrons. Here we need to explore how aid - in all its complex forms - is negotiated, implemented, monitored and evaluated. In this we draw on the preliminary research of Wrighton (2010; Wrighton and Overton, 2012) on aid in Tuvalu. Wrighton suggests that the practice of aid in Tuvalu is rather different from, and sometimes contradictory to, the rhetoric of the Paris Declaration and its support for recipient ownership. In Tuvalu, with its small population and small, overstretched local bureaucracy, the requirements of donors to comply with the plethora of their financial management systems, audits, consultative mechanisms, plans and so on, place a very high burden on the few officials who have to implement the nation state's administration and development. A wide range of donors bilateral partners such as Australia, Japan and New Zealand, multilateral agencies, and regional organisations - seek to meet, discuss, coordinate, align and manage a long list of programmes and projects with a handful of local officials. Ostensibly then, the Paris Declaration principles of 'alignment' and 'managing for results' are adhered to and the key principle of 'ownership' is respected by donors in the holding of frequent meetings and consultations. In reality the actual practice is that donor harmonisation is very poorly achieved and the substance of the ownership is effectively undermined by the complexity and magnitude of donor requirements, or - alternatively - effectively traded by the aid recipient. We regard this as a second element of the inverse sovereignty effect: the new aid regime, despite the rhetoric of country ownership, is actually diminishing the ability of recipient governments and communities to exercise selfdetermination because of the burden of compliance and the new process-conditionalities of aid (Murray and Overton, 2011b; Gould, 2005).

Therefore, it is argued here that we need to take a much more geographically detailed and more critical view of sovereignty in Oceania. Sovereignty is neither simple nor absolute. It is about the political and legal status of a territory but also critically about the ability of those involved in governance and administration to exercise effective control over their own development and their own resources. Sovereignty, as we define it, is multi-dimensional and heterogeneous, it is flexible and malleable and it is continually contested and negotiated at a local scale through everyday interactions that contain both overt and subtle performances of power. Aid lies at the centre of many of these dialectical performances, simultaneously espousing local sovereignty, whilst acting to undermine it.

\section{The Inverse Sovereignty Effect: A Research Agenda}

The above framing of aid and sovereignty in Oceania provides the context for a research project being carried out through Victoria University of Wellington and the University of the South Pacific that is supported by the Marsden Fund in New Zealand. A three year project running from 2011 to 2013, it examines the way the global aid regime of the past decade and its associated modalities have been put into practice in the Pacific region. Its central hypothesis is the inverse sovereignty effect noted above: how at one level state sovereignty seems to be inversely related to development and welfare; and, crucially, at another, how the aid regime of the past decade actually diminishes territorial selfdetermination by placing unreasonable burdens of compliance and consultation on small underresourced institutions.

The project builds on Wrighton's research in Tuvalu and explores further Pacific case studies that add other dimensions to our understanding by including territories of different size, political status and past colonial affiliation. As well as the Tuvalu work, the proposed core case studies will include territories that have agreed to participate and may include the Cook Islands, Kiribati, the Marshall Islands, Tonga and Vanuatu. Other studies will examine related aspects of aid and development in New Caledonia, Samoa, Solomon Islands, Rapa Nui and Niue and a linked project will examine the role of civil society in promoting local self determination over aid. For the core studies a set of markers of development sovereignty will be used to measure the degree to which local individuals and institutions have exercised forms of control over aid negotiations and implementation. Through an active programme of participation by Pacific governments, it is planned to develop a series of practical recommendations that countries - both recipients and donors - can use to help enhance effective sovereignty and, thus development and aid effectiveness. 
Initial findings from the research reveal a diversity of experiences and practices across the region. It is clear that the new aid regime has had a significant impact in the way aid programmes are negotiated and implemented. Administrative burdens have increased and lack of capacity can be identified in several areas. For some countries, such as Tuvalu, the burden of consultation and compliance is very high. Yet there are also instances where, within limits, local institutions and individuals are able effectively to engage with and use the principles of the agenda - especially the concepts of ownership and alignment - to assert a good degree of local control. In Samoa, for example, a particularly confident and assertive approach to the aid effectiveness agenda has allowed officials to maintain and arguably increase the opportunities for local development sovereignty. It remains to be seen, however, what the effect of relative political independence/ dependence is on this ability to leverage local policy space.

\section{Conclusions}

This paper has outlined a research project on aid in the Pacific. We argue that there is considerable potential for this work to reshape our understanding of aid and development not only in Oceania but also globally. Within the Pacific there is clearly a pressing need to question and reconfigure our existing frames of reference for aid. We argue that the OECD/DAC apparatus for defining and measuring aid is but a partial and inadequate mechanism. In the Pacific in particular it misses many flows that might justifiably be termed 'aid': non financial instruments to do with labour movement, remittances and trade; the substantial flows of resources to territories which are integrated in politically diverse ways to their metropoles; and the operations of nonDAC donors such as China. These are all of vital importance in the region, and arguably more apparent than in other aid receiving regions. If we broaden our scope to include such forms of aid, this leads us to question our very concept of aid. This might move the work in the direction of Severino's (2011) suggestions regarding the future of development assistance: aid as global social policy and aid as a means to compensate for the social and environmental externalities of globalisation. Or it might take a more radical post-development and postcolonial direction, criticising aid as a tool of external control and exploitation. Alternatively it might merely reveal that aid is but one element in complex and multi- layered relationships between territories. Aid is rarely a matter of absolutes or clearly defined mechanisms and flows but rather a complex set of linkages, mutually constitutive flows, asymmetrical power relationships and fluid political assemblages.

Finally, we argue that we need to look at the concept of sovereignty much more closely in relation to aid. Sovereignty is about the exercise of power and self-determination. As with aid, our conventional frameworks and definitions of sovereignty are limited and overly rigid thus obscuring a deeper understanding of how power is exercised with and through aid. In this regard, throughout this project it will be critical to adopt a perspective on the region that recognises and celebrates the potential for local agency. Too often, critiques of aid commit the error of what we term here scalar determinism - that the global overwhelms the local and thus structure determines agency. Such critiques emphasise the overwhelming power of donors and the global aid 'industry' and, by implication, the weakness and helplessness of recipients. This has been illuminated by post-development theories which point to the discourse of development which, through the very use of terms such as 'aid', 'recipient', 'donor' and 'progress', posit a highly unequal relationship, demarcate arenas where power is exercised in only one direction, and present 'development' and 'aid' as essentially unproblematic and uncontestable concepts. Indeed, such a project could easily succumb to the simplistic view that donors hold all the power, that small Pacific Island bureaucracies are incapable of resistance and that all aid is somehow malevolent; merely a tool for oppression and exploitation of the region. Yet the challenge for the project is to find space for local agency: to uncover strategies used by Pacific people and institutions to resist, subvert, co-opt or steer the aid regime in their own ways to help promote their own effective sovereignty over development. Doing so requires a more sophisticated conceptualisation of the interaction between process at different scales and the relationship between structure and agency.

By sharing such knowledge and support amongst Pacific territories and also by alerting donors to the pressing need to recognise the essence of 'ownership' we hope to contribute to a reformed and more effective aid landscape in the region. Furthermore, it is hoped that the understandings to be gained from the Pacific may have resonance more widely. We believe there is considerable scope for Pacific perspectives to challenge and contribute to evolving 
conceptions and practices of aid and sovereignty. To close, we reiterate that aid in the Pacific has not lived up to the rhetoric of local ownership with effective practice but, despite its profound shortcomings, we see potential for aid to precipitate positive change. Such a reformed aid landscape would facilitate Pacific peoples and their institutions to regain and sustain control over their land, resources and decision making processes. This, in turn, would provide opportunities to pursue what they themselves define as desirable development strategies and outcomes.

\section{BIBLIOGRAPHY}

BARBARA Julien, 2008. Rethinking neo-liberal state building: Building post-conflict development states, Development in Practice 18, 3, pp. 307-318.

Baudchon Gérard et Jean-Louis Rallu, 1999. Changement démographique et social en NouvelleCalédonie après les accords de Matignon, Population 54, 3, pp. 391-425.

Bertram Ivo Geoffrey, 2004. On the convergence of small island economies on their metropolitan patrons, World Development 32, 2, pp. 343-364.

- 2006. The MIRAB model in the twenty-first century, Asia Pacific Viewpoint 47, 1, pp. 1-13.

Bertram Ivo Geoffrey and Ray F. Watters, 1985. The MIRAB economy in South Pacific microstates, Pacific Viewpoint 26,3, pp. 497-519.

Booth David (ed.), 2003. Fighting Poverty in Africa: Are PRSPS Making a Difference?, London, Overseas Development Institute.

Bоотн David, 2011. Aid, institutions and governance: What have we learned?, Development Policy Review 29, s1, pp. s5-s26.

BUITER Willem H. 2007. 'Country ownership': A term whose time has gone, Development in Practice 17,4-5, pp. 647-652.

Chand Satish, 2011. Who receives Australian aid, and why?, Development Policy Centre Discussion Paper 6, Canberra, Crawford School of Economics and Government, The Australian National University.

Cheru Fantu, 2006. Building and supporting PRSPs in Africa: What has worked well so far? What needs changing?, Third World Quarterly 27, 2, pp. 355376.

De Renzio Paolo, 2006. Aid, budgets and accountability: A survey article, Development Policy Review 24, 6, pp. 627-645.

De Renzio Paolo, 2009. Taking Stock: What Do PEFA Assessments Tell Us about PFM Systems Across Countries?, London, Overseas Development Institute.
DiJKstra Geske and Kristin Komives, 2011. The PRS approach and the Paris Agenda: Experiences in Bolivia, Honduras and Nicaragua, European Journal of Development Research 23, 2, pp. 191-207.

DINNEN Sinclair, 2004. Lending a fist? Australia's new interventionism in the Southwest Pacific, State, Society and Governance in Melanesia, Discussion paper 2004/5, Canberra, Research School of Pacific and Asian Studies, Australian National University.

DinNen Sinclair and Stewart FIRTH (eds), 2008. Politics and State Building in Solomon Islands, Canberra, Asia Pacific Press, The Australian National University.

Dobell Graeme, 2007. The 'arc of instability': The history of an idea, in Ron Huisken and Meredith Thatcher (eds), History as Policy: Framing the Debate on the Future of Australia's Defence Policy, Canberra, ANUE press, pp. 85-104.

Driscoll Ruth and Allison Evans, 2005. Second generation poverty reduction strategies: New opportunities and emerging issues, Development Policy Review 23, 1, pp. 5-25.

EIFERT Benn and Alan Gelb, 2008. Reforming aid: Toward more predictable performance-based financing for development, World Development 36,10, pp. 2067-2081.

EyBEN Rosalind, 2007. Harmonisation: How is the orchestra conducted?, Development in Practice 17, 4-5, pp. 640-646.

Feeny Simon and Matthew Clarke, 2008. Achieving the Millennium Development Goals in the AsiaPacific region: The role of international assistance, Asia Pacific Viewpoint 49, 2, pp. 198-212.

FRY Greg, 1997. Framing the Islands: Knowledge and power in changing Australian images of the South Pacific, The Contemporary Pacific 9, 2, pp. 305-44.

Gould Jeremy, 2005. The New Conditionality: The Politics of Poverty Reduction Strategies, London, Zed Books.

Hadj Laure, Gaël Lagadec, Gérard Lavigne et Catherine RIs, 2011. Les inégalités ethniques devant l'école en Nouvelle-Calédonie, Nouméa, Laboratoire de Recherches juridique et économique (LARJE).

Hansen Fergus, 2008. The Dragon Looks South, Sydney, Lowy Institute for International Policy.

Hau'ofa Epeli, 1995. Our sea of islands, in Eric Waddell, Vijay Naidu and Epeli Hau'ofa (eds), $A$ New Oceania: Rediscovering Our Sea of Islands, Suva, University of the South Pacific, pp. 38-48.

Herrera Javier and Sébastien Merceron, 2010. Les approches de la pauvreté en Polynésie française : résultats et apports de l'enquête sur les conditions de vie en 2009, Paris, Agence française de Développement.

Howell Jude and Jeremy LIND, 2008. Changing donor policy and practice in civil society in the post-9/11 aid context, Third World Quarterly 30, 7, pp. $1279-1296$. 
Institut D'ÉMission DE L'OUTRE-MER (IEOM), 2011. Nouvelle-Calédonie. Rapport Annuel 2010, Paris, IEOM.

KIDU Carol, 2009. Maternal health in Papua New Guinea: Reality, challenges, and possible solutions, in Jonathan Boston (ed.), Eliminating World Poverty: Global Goals and Regional Progress, Wellington, Institute of Policy Studies, pp. 179-186.

Koeberle Stephan, Zoran Stavreski and Jan WALliser (eds), 2006. Budget Support as More Effective Aid? Recent Experiences and Emerging Lessons, Washington DC, World Bank.

MawdSLEy Emma, 2010. The Non-DAC donors and the changing landscape of foreign aid : the (in)significance of India's development cooperation with Kenya, Journal of Eastern African Studies 4, 2, pp. 361-79.

Mohan Giles and Marcus Power, 2009. Africa, China and the 'new' economic geography of development, Singapore Journal of Tropical Geography 30, 1, pp. 24-28.

Murray Warwick E. and John D. Overton, 2011a. Neoliberalism is dead, long live neoliberalism? Neostructuralism and the international aid regime of the 2000s, Progress in Development Studies 11, 4, pp. 307-319.

—, 2011b. The inverse sovereignty effect: Aid, scale and neostructuralism in Oceania, Asia Pacific Viewpoint 52, 3, pp. 272-284.

NAIDU Vijay, 2009. Changing gears on the Millennium Development Goals in Oceania, in Jonathan Boston (ed), Eliminating World Poverty : Global Goals and Regional Progress, Wellington, Institute of Policy Studies, pp. 103-126.

NAIDU Vijay and Terence Wood, 2008. A Slice of Paradise? The Millennium Development Goals in the Pacific: Progress, Pitfalls and Potential Solutions, Working Paper 1, Oceania Development Network, Apia, National University of Samoa.

Nedelec Michel, 2010. L'évolution économique et sociale de Wallis, retrieved 21 September 2012 (http://www.ac-noumea.nc/histoire-geo/spip/spip. php?article107\&lang=fr).

New Zealand House of Representatives, 2010. Inquiry Into New Zealand's Relationships with South Pacific Countries. Report of the Foreign Affairs, Defence and Trade Committee, Wellington, New Zealand House of Representatives.

Prinsen Gerard, 2011. Negotiating on a Seesaw. Decentralisation of Education and Health Services in Uganda and Tanzania from a Local Perspective and in a Historical Context, $\mathrm{PhD}$ thesis, Palmerston North-New Zealand, Massey University.

Ratuva Steven, 2011 (2 May). The Chinese lake, The Listener.

Santiso Carlos and Paul H. Nitze, 2001. Good governance and aid effectiveness: The World Bank and conditionality, The Georgetown Public Policy Review 7, 1, pp. 1-19.

SEVERINO Jean-Michel, 2011. The resurrection of aid, in OECD Development Co-operation Report 2011: $50^{\text {th }}$ Anniversary Edition, Paris, OECD, pp. 121-133.

SHANNON Róisín, 2009. Playing with principles in an era of securitized aid: Negotiating humanitarian space in post-9/11 Afghanistan, Progress in Development Studies 9, 1, pp. 15-36.

StOrey Donovan, 2004. The Fiji Garment Industry, Auckland, Oxfam New Zealand.

Storey Donovan, Hannah Bulloch and John Overton, 2005. The poverty consensus: Some limitations of the 'popular agenda', Progress in Development Studies 5, 1, pp. 30-44.

Sumner Andrew, 2006. In search of the PostWashington (Dis)consensus: The 'missing' content of PRSPs, Third World Quarterly 27, 8, pp. 14011412.

Tabutaulaka Tarcisius Tara, 2005. Australian foreign policy and the RAMSI intervention in the Solomon Islands, The Contemporary Pacific 17, 2 pp. 283-308.

TAYLOR Michael (ed.), 1987. Fiji: Future Imperfect?, Sydney, Allen and Unwin.

Usa OfFice OF Insular AfFairs, 2011. Insular Area Summary for American Samoa (http://www. doi.gov/oia/Islandpages/asgpage.htm, accessed 25 November 2011).

WeSLey-Smith Terence, 2007. Self-determination in Oceania, Race and Class 48, 3, pp. 29-46.

Williams David, 2000. Aid and sovereignty: Quasistates and the international financial institutions, Review of International Studies 26, 4, pp. 557-573.

Wrighton Nicki, 2010. Participation, power and practice in development: A case study of theoretical doctrines and international agency practice in Tuvalu, unpublished MDevStuds thesis, Wellington, Victoria University of Wellington.

Wrighton Nicki and John Overton, 2012. Coping with participation in small island states: The case of aid in Tuvalu, Development in Practice 22, 2, pp. 244-255. 